\title{
THE SELENIUM CONTENT OF FINNISH FORAGE CROPS
}

\author{
H. E. Oksanen and Markus Sandholm \\ College of Veterinary Medicine, Department of Medicine, Helsinki
}

Received April 3, 1970

The importance of selenium in plants was first realised in the 1930's, when it was found that "alkali disease» and »blind staggers» of cattle and horses in the United States of America were caused by the animals eating plants containing a high concentration of selenium (BеAтH et al. 1934). The biological significance of selenium was believed to be restricted to its toxicity until Schwarz and Foltz (1957) showed that Factor-3, which protects rats against liver necrosis, was a selenium compound. It was subsequently established that selenium is an essential trace element which will protect animals against a variety of diseases that were previously thought to be due primarily to vitamin E deficiency (Schwarz 1961). One of the most important diseases of farm animals, now known to be associated with a low selenium intake, is nutritional muscular degeneration (NMD) in ruminants.

Research in many countries has shown that NMD in ruminants is associated with low selenium concentrations in the diet (HARTLEY \& GRANT 1961, Gardiner et al. 1962, Allaway \& Hodgson 1964). This in turn has stimulated the development of accurate methods of measuring small amounts of selenium in biological material (WoLF et al. 1963, WATKINSON 1966, LiNDBERG 1968).

In Finland, NMD in cattle has caused considerable economic losses (ANDERsson 1960, OKSANEN 1965), and although the results of selenium treatment have generally been good, there have been conflicting reports on the selenium content of forage plants in Ostrobothnia, where the disease was once most common (Andersson 1960, Westermarck 1964, OKSANEN 1965). In view of this, it was considered important to re-examine the selenium content of Finnish forage plants collected from different parts of the country.

\section{Material and Methods}

During the crop years 1968 and 1969, 145 plant samples were collected from 13 different field stations belonging to the Agricultural Research Centre in Finland. The samples were ground and their dry weights determined. The selenium content of samples weighing $10-25 \mathrm{~g}$ was determined by the method of LiNDBERG (1968). The material was wet-ashed with a mixture of nitric and perchloric acids, the selenium extracted with toluene 3,4dithiol, and 2,3-diaminonaphthalene was used as a fluorescing reagent. The recovery 
of the selenium was measured by using $\mathrm{Se}^{75}$ as a tracer, the radioactivity being measured with a NaI-crystal computer before and after handling.

\section{Results}

The results are set out in Table I. The mean concentration of selenium in hay and grain samples was $0.014 \mathrm{ppm}(14 \mathrm{ppb})$ and $0.007 \mathrm{ppm}$ (7 ppb), respectively. The samples with the highest concentration came from the most northerly station at Rovaniemi. There was no correlation between the selenium content in the plants and the type of soil in which the plants were grown.

Table 1. Selenium content (p.p.b*) in forage (dry matter).

\begin{tabular}{|c|c|c|c|c|c|c|c|c|c|c|c|c|c|c|c|c|}
\hline \multirow{2}{*}{$\begin{array}{l}\text { Locality of } \\
\text { field station }\end{array}$} & \multicolumn{4}{|c|}{ Barley } & Rye & \multicolumn{2}{|c|}{ Oat } & \multicolumn{2}{|c|}{ Wheat } & Timothy & \multicolumn{2}{|r|}{ Clover } & \multicolumn{2}{|c|}{$\begin{array}{l}\text { Pasture } \\
\text { grasses }\end{array}$} & Pea & \multirow[t]{2}{*}{ Rape } \\
\hline & $n$ & $\overline{\mathbf{x}}$ & & $\mathbf{n}$ & $\overline{\mathrm{x}} \mathrm{s}$ & $\mathrm{n} \overline{\mathrm{x}}$ & $\overline{\mathbf{x}} \mathbf{s}$ & $\mathrm{n} \overline{\mathrm{x}}$ & $\overline{\mathbf{x}} \mathbf{s}$ & $\mathrm{n} \overline{\mathrm{x}} \mathrm{s}$ & $\mathbf{n}$ & $\overline{\mathbf{x}} \mathbf{s}$ & $\mathbf{n}$ & $\overline{\mathrm{x}} \mathrm{s}$ & $f \overline{\mathrm{x}} \mathrm{s}$ & \\
\hline Anjala & 1 & 7 & 4 & 1 & 3 & 11 & 11 & 26 & $6 \pm 2$ & 17 & & & & & & \\
\hline Kokemäki & 1 & 7 & & & & 11 & 13 & 18 & 85 & 114 & 1 & 12 & & & & \\
\hline Laukaa & $4:$ & 3 & \pm 4 & 1 & 2 & 23 & $3 \pm 1$ & & & $5 \quad 17 \pm 16$ & 4 & $18 \pm 14$ & 5 & $8 \pm 4$ & & \\
\hline Maaninka & 2 & 3 & \pm 3 & 1 & 2 & 17 & 7 & & & 15 & & & & & & \\
\hline Mietoinen & & & & & & & & & & 111 & 1 & 6 & & & & \\
\hline Mikkeli & $1:$ & 3 & & 1 & 7 & 11 & 15 & & & $47 \pm 1$ & 2 & $8 \pm 2$ & 2 & $10 \pm 1$ & & \\
\hline Mouhijärvi & & & & 1 & 6 & 29 & $9 \pm 6$ & & & $311 \pm 1$ & 1 & 8 & & & & \\
\hline Pello & & & & & & & & & & $46 \pm 2$ & 1 & 4 & 1 & 2 & & \\
\hline Pälkäne & 1 & 4 & & & & 15 & 5 & 24 & $4 \pm 1$ & $315 \pm 4$ & 3 & $22 \pm 6$ & 3 & $12 \pm 4$ & 13 & \\
\hline Rovaniemi & 3 & & \pm 15 & & & 11 & 18 & 17 & 7 & $539 \pm 26$ & 3 & $19 \pm 7$ & 3 & $48 \pm 23$ & & 143 \\
\hline Ruukki & $6:$ & 3 & \pm 1 & 1 & 4 & 23 & $3 \pm 1$ & & & $812 \pm 4$ & & & 6 & $10 \pm 3$ & & \\
\hline Tohmajärvi & 2 & 7 & \pm 4 & 2 & $6 \pm 0$ & & & & & $58 \pm 1$ & 1 & 12 & 10 & $10 \pm 3$ & & \\
\hline Ylistaro & $2:$ & 2 & \pm 1 & 1 & 5 & 27 & $7 \pm 4$ & & & $38 \pm 2$ & & & & & & \\
\hline
\end{tabular}

\section{Discussion}

The low selenium values obtained in this study are similar to those reported from other countries in forage known to cause selenium deficiency diseases in animals. Oldfield et al. (1963) reported that they could provoke NMD in lambs with a hay-oat diet containing less than $0.02 \mathrm{ppm} \mathrm{Se}$ and that the disease was prevented, when the selenium concentration was raised to $0.06 \mathrm{ppm}$. Most of the field cases of selenium responsive diseases in ruminants have occurred in young lambs and calves from dams that have been kept on feeds containing less than 0.05 to $0.10 \mathrm{ppm}$ Se (Allaway et al. 1967). The observed critical minimum levels of selenium required in animal diets vary from less than 0.03 to 0.3 ppm Se (Allaway et al. 1967).

In preliminary investigations it was found that hay samples collected in 1965 from South-Ostrobothnia contained 0.01 to $0.02 \mathrm{ppm}$ Se, while hay samples collected previously from the same area contained 0.013 to 0.081 (mean 0.032 ) ppm Se. A barley sample contained 0.014 and an oat sample less than 0.010 ppm Se (OKsAnen 1965) These results were obtained by the use of neutron activation analysis and the accuracy was restricted by the low power of the reactors used. The fluorescence method used in the present study is suitable for determining low selenium contents in biological material (WATKINson 1966), 
and the use of the $\mathrm{Se}^{75}$ tracer, to measure the loss of selenium during the analysis, increases the reliability of the method.

Low selenium content in plants is not necessarily related to the soil selenium content, as selenium in the soil may occur in forms that the plant cannot utilize. For example in acid environments compounds of selenium and iron may occur, from which plants are unable to absorb selenium (Trelease \& BeATH 1949). Likewise, the content of sulphur in the soil affects the availability of selenium to the plant (HURD-KARRER 1934).

In Finland, especially in Ostrobothnia, there are acid "sulphate soils" rich in iron and sulphur (Krvinen 1950) and it is possible that this may account for the low selenium content of plants in this area. However, it is known that the plutonic and metamorphic rock in the whole country is especially low in selenium, about $0.06 \mathrm{ppm}$ (KoLJONEN 1965). Consequently it appears that the low soil selenium content is the main reason for the low selenium values in forage plants in Finland.

The selenium responsive diseases are not necessarily simple selenium deficiencies. Vitamin E, unsaturated fatty acids, sulphur containing amino acids and possible other factors, are involved. For example in Ostroborhnia, where NMD was a common disease prior to selenium supplementation, it was found that yearly fluctuations in incidence could be related to variations in the vitamin $\mathrm{E}$ content of hay, which was dependent on harvesting conditions (OKsanen 1965, Thafvelin \& OKsanen 1966). Notwithstanding this complex aetiology, NMD can be prevented and cured by selenium.

From the results of the present study it would appear that the selenium content of hay and grain in Finland is so low that selenium responsive diseases may be expected to occur anywhere in the country unless selenium supplementation is practised.

\section{Summary}

The total of 145 plant samples were collected from 13 field stations in Finland during the crop years 1968 and 1969 and analysed for selenium by a fluorescence method using 2,3-diaminonaphthalene as the fluorescing reagent. The loss of selenium during analysis was measured by a $\mathrm{Se}^{75}$ tracer.

The selenium content of all samples was very low. The mean value for hay samples was $0.014 \mathrm{ppm}$ (range 0.002 to 0.048 ), and for grain samles $0.007 \mathrm{ppm}$ (range 0.002 to 0.085 ). The samples with the highest selenium content came from Lapland (Rovaniemi), where the mean values for hay and grain were $0.036 \mathrm{ppm}$ and $0.013 \mathrm{ppm}$ respectively. There was no correlation between the plant selenium content and soil type.

It appears that selenium deficiency diseases may occur anywhere in Finland unless Se supplementation is carried out.

Acknowledgements: This work received financial assistance from the State Medical Committee. The radioactivity measurements were carried out in the Isotope Labcratory, Faculty of Agriculture and Forestry, University of Helsinki.

\section{REFERENCES}

Allaway, W. H., Cary, E. E. \& Ehlig, C. F. 1967. The cycling of low levels of selenium in soils, plants and animals. Selenium in Biomedicine, First Intern. Symposium, AIV Publish, Comp., p. 273296. 
Allaway, W. H. \& Hodgson, J. F. 1964. Selenium in forages as related to the geographic distribution of muscular dystrophy in livestock. J. Anim. Sci. 23: 271-277.

Andersson, P. 1960. Nutritional muscular dystrophy in cattle with special reference to the functional state of the thyroid. Acta path.microbiol.scand., suppl. 134.

Beath, O. A., Draize, J. H., Eppson, H. F., Grlbert, C. S. \& Mc Creary, O. C. 1934. Certain poisonous plants of Wyoming activated by selenium and their association with respect to soil types. J. Am. Pharm. Assoc. Sci. Ed. 23: 94-97.

Gardiner, M. R., Armstrong, J., Fels, H. \& Glencross, R. N. 1962. A preliminary report on selenium and animal health in Western Australia. Aust. J. exp. Agric. Anim. Hubs. 2: 261-269.

Hartley, W. J. \& Grant, A. B. 1961. A review of selenium responsive diseases of New Zealand livestock. Fed. Proc. 20: 679-688.

HUrd-KArRer, A-M. 1934. Selenium injury to wheat plants and its inhibition by sulphur. J. agric. Res. 49: $343-357$.

Krvinen, E. 1944. Sulfat- eller alunjordar, deras egenskaper och synpunkter på deras odling. Sv. Valloch Mosskulturför. T. 2: 1-13.

Koljonen, T. 1965. Seleenin esiintymisestä suomalaisissa kivissä. Unpublished thesis. Arch. of Geology and Mineralogy, Univ. Helsinki.

LindBerg, P. 1968. Selenium determination in plant and animal material, and in water. Âcta vet. scand., suppl. 23.

OKsanen, H. . 1965. Studies on nutritional muscular degeneration (NMD) in ruminants. Ibid. suppl. 2.

Oldfield, J. E., Schubert, J. R. \& MUth, O. H. 1963. Implications of selenium in large animal nutrition. J. Agric. Food. Chem. 11: 388-390.

Schwarz, K. 1961. Development and status of experimental work on Factor 3-selenium. Fed. Proc. 20: $666-673$.

Schwarz, K. \& Foltz, C. M. 1957. Selenium as an integral part of Factor 3 against dietary nectotic liver degeneration. J. Amer. chem. Soc. 79: 3292.

Thafvelin, B. \& Oksanen, H. E. 1966. Vitamin E and linolenic acid content of hay as related to different drying conditions. J. Dairy Sci. 49: 282-286.

Trelease, S. F. \& Beath, O. A. 1949. Selenium. 292 p. New York.

WAtkinson, J. H. 1966. Fluorometric determination of selenium in biological material with 2,3- diaminonaphthalene. Anal. Chem. 38: 92-97.

Westermarck, H. 1964. Selenium in the prevention and therapy in white muscle disease in calves and heifers. Nord. Vet. -Med. 16: 264-274.

Wolf, E., Kollonotsch, V. \& Kline, C. H. 1963. A survey of selenium treatment in livestock production. J. Agric. Food Chem. 11: 355-360.

\section{SELOSTUS}

\section{REHUJEN SELEENIPITOISUUS MAASSAMME}

H. E. Oksanen ja Markus Sandholm

\section{Eläinlääketieteellinen korkeakoulu, Sisätautiopin laitos, Helsinki}

Vuosien 1968 ja 1969 sadoista eri puolilta maata sijaitsevilta koeasemilta kerätyn 145 kasvinäytteen seleenipitoisuus määrättiin fluoresenssimenetelmällä käyttäen 2,3- diaminonaftaleiinia ja kontrolloimalla tapahtuneet seleenitappiot $\mathrm{Se}^{75}$-lisällä.

Seleenipitoisuus oli erittäin alhainen kaikissa näytteissä (Taulukko 1). Keskiarvo heinänäytteissä oli

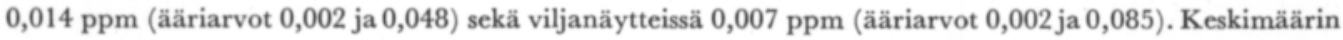
korkeimmat seleeniarvot todettiin Perä-Pohjolan (Rovaniemi) koeasemalta kerätyissä näytteissä. Kasvualustan maaperän ja kasvien seleenikonsentraation välillä ei voitu osoittaa korrelaatiota.

Todetuista erittäin alhaisista seleeniarvoista voidaan päätellä, että seleenin puutteen aiheuttamia kotieläinten tauteja saattaa esiintyä kautta koko maan, mikäli seleenitarvetta ei ole tyydytty erityisellä selecnilisällä. 